\title{
The possible effect of re-opening of the Väike Strait (Baltic Sea): results of high-resolution modelling
}

\author{
Ü. Suursaar, T. Kullas \& M. Otsmann \\ Estonian Marine Institute, University of Tartu, Estonia
}

\begin{abstract}
In recent decades, the ecological condition is said to be deteriorating in the area of the Väike Strait in the West Estonian Archipelago. The strait has been closed by a $3 \mathrm{~km}$-long road dam since 1896 and according to widespread opinion, as no water exchange between the Gulf of Riga and the Väinameri Sea occurs through this strait, the existence of the dam should be the main reason for those adverse changes. The main aims of the study are to analyse the past changes in the Väike Strait area, and to decide whether re-opening of the strait by constructing some bridged openings can improve the situation. The possible influence of holes were analysed by the means of high-resolution (size of the grid $200 \mathrm{~m}$ ) twodimensional hydrodynamic modelling. Renewal times of water masses were calculated. The results on water and matter exchange suggested that the planned holes probably have a very small positive effect. The water exchange, depending on the scenario, increased only by about $6-12 \%$, and yet in the zones nearby the dam. Most of the past changes have probably occurred either due to natural or of larger scale causes, such as isostatic land uplift, natural sedimentation and overall eutrophication of the sea. They cannot be turned back merely by constructing the openings, or even by entirely re-opening the strait.
\end{abstract}

Keywords: water exchange, flow modelling, sea level, sea bottom, nutrients, Baltic Sea.

\section{Introduction}

West Estonian coastal sea is a vital economic and cultural resource for the population of Estonia and Latvia (Fig. 1). The shallow and naturally diverse marine environment consists of semi-enclosed sub-basins, zone of straits, 
numerous islands and shoals, where large reproduction areas of herring, eel, whitefish, garfish and pikeperch locate. The aquatic areas of the Väinameri Sea (Archipelago Sea) together with a narrow strip of mainland serve as the biosphere reserve of UNESCO-s Man and Biosphere Program, as well as for Natura 2000. In the Matsalu National Park of Ramsar convention, floodplains, reedbeds and islets provide nesting and moulting grounds for some 282 species of birds. However, growing human pressure, eutrophication of the sea and localscale pollution has adversely impacted the coastal marine environment over the last decades [1]. Assessing past and present ecological developments in this vulnerable area is therefore of considerable importance, serving as a tool for management of water resources and safeguarding the sustainable use of the ecosystems goods.

Within the Väinameri Sea, the Väike Strait locates between the islands of Saaremaa and Muhumaa (Figs. 1, 2). It has been closed by a $3 \mathrm{~km}$-long road dam since 1896 . Hence, it is actually not a strait any more, but two relatively shallow bays. In recent decades, the ecological condition is said to be deteriorating in the area, fish stocks are declining, acceleration of accumulation and eutrophication processes have been observed [2-4]. According to a widespread opinion, as no water exchange between the Gulf of Riga and the Väinameri Sea occurs through the Väike Strait, the existence of the dam should be the main reason for those adverse changes. Therefore, a question of re-opening of the strait by constructing some bridged openings has risen several times in the past: in 1993 [3], 1999 [5], and most recently in 2008. The paper summarizes our last results on that issue. The main aims of the study are to analyse the past changes in the Väike Strait area, and to decide whether the planned holes have the desired effect on water exchange and on restoring the past situation.

\section{Study area}

The hydrophysical and chemical regime of the study area is determined by the conditions of the Väinameri Sea and the Gulf of Riga, respectively. The Gulf of Riga has an area of $17913 \mathrm{~km}^{2}$ and a average depth of $23 \mathrm{~m}$, while the Väinameri has an area of $2243 \mathrm{~km}^{2}$ and a depth of $4.7 \mathrm{~m}$. Due to differences in riverine and nutrient inflows, the trophic status of these sub-areas is quite different. While the salinity is just somewhat higher in the Väinameri (typically 6-6.7 against 5.5-6.2 in the northern part of the Gulf of Riga), the difference in nutrient concentrations, especially in Ntot, is far more remarkable [2, 6]. Therefore, considerable water and matter exchange proceeds through the straits between these two sub-basins, as well as between them and the Baltic Proper.

The main strait of the system (Fig. 1) is the Suur Strait ("big strait" in Estonian), which has a width of $4 \mathrm{~km}$ and maximum depth of $21 \mathrm{~m}$. The nearly parallel Väike Strait (or "small strait") is actually not a strait since 1896. The construction work of the dam began in 1892 and the opening of the road link between the Saaremaa and Muhumaa islands (Fig. 2) took place on 27 July 1896. The north-western half of the strait (or the NW-bay, to be more precise) has a length of about $11 \mathrm{~km}$ and the area of $38 \mathrm{~km}^{2}$ (Table 1). Taking into account the 
average depth of the basin $(1.6 \mathrm{~m})$, the average water volume is about $63000000 \mathrm{~m}^{3}$. The SE-bay has the inner and the outer part. The inner $(8 \times 3 \mathrm{~km})$ basin is very shallow (average depth $0.6 \mathrm{~m})$. The outer part $(6 \times 5 \mathrm{~km})$ is deeper (about $3 \mathrm{~m}$ ) and the volume is nearly 15 times larger than that of the inner part of the SE-bay. In the NW-bay fine sands and aleurites dominate as the bottom sediments. In the SE-bay coarse and medium sands prevail, which change to aleurites in the outer bay [6, 7]. A muddy bottom can be found in the nearshore and near-dam sections of the study area. In recent years a sub-surface sandy bank has risen in the central part of the inner bay. In the case of low sea level it may emerge as a shoal, leaving free water either near the coasts of Saaremaa or Muhumaa. The study area is practically tideless, however, the meteorologically forced sea level variations may reach up to $3 \mathrm{~m} \mathrm{[8].}$

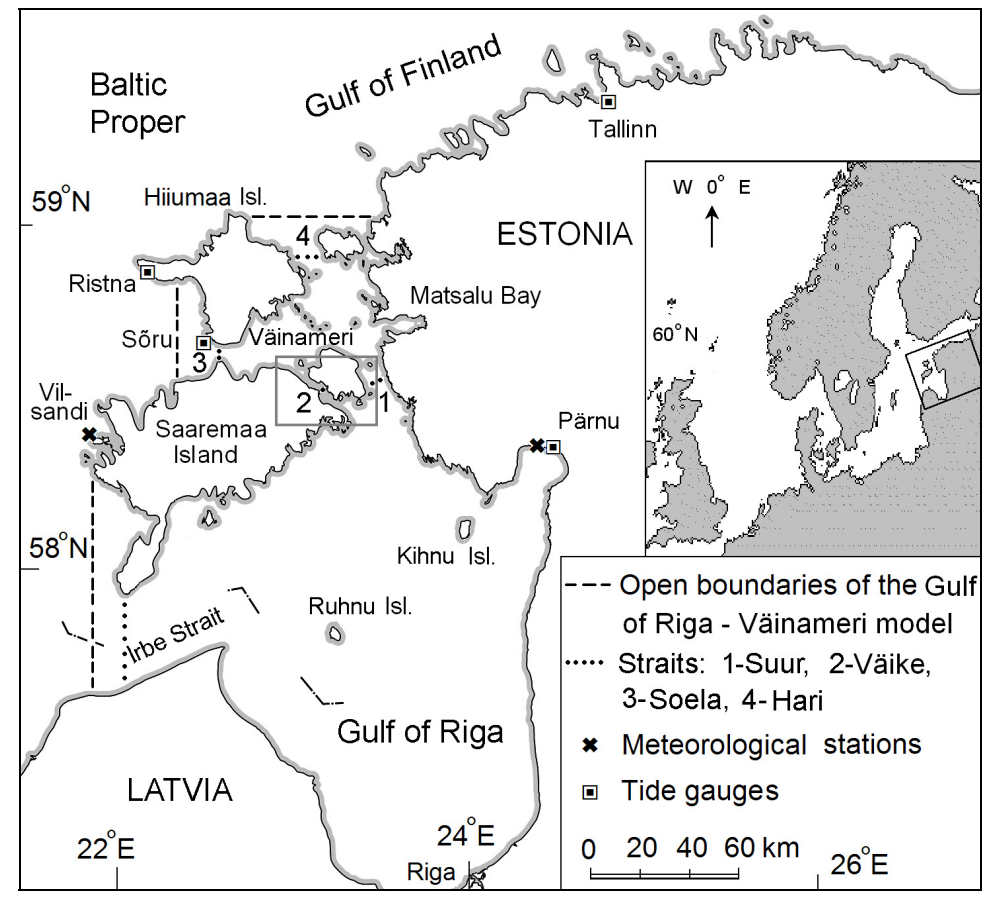

Figure 1: $\quad$ Map of the West Estonian Archipelago Sea (Väinameri) and the Gulf of Riga with borders of 2D hydrodynamic model domain. The specific (nested) study area of the Väike Strait is marked with "2".

\section{Material and methods}

The analysis of the past and present situation was based on the data of national marine monitoring, which is carried out by the Estonian Marine Institute since 1993, as well as on special measurements in the area (e.g. in 1993, 1996, 2007). 
They include data on nutrient concentrations, oxygen, water temperature and salinity, as well as some hydrobiological variables (which are not considered here).

The basic hydrodynamic properties, as well as the possible influence of holes were analysed by the means of several relatively simple hydrodynamic models. They include, firstly, a two-basin five-channel forced oscillation model of Helmholtz-type [9]. The model is forced by wind and sea level data and it calculates sea level variations within the two sub-basins and water fluxes in the channels (straits) without any spatial resolution, though. Then, a 2D hydrodynamic model with the grid step of $1 \mathrm{~km}$ has 16405 marine points in the Gulf of Riga and 2510 points in the Väinameri (Fig. 1). The depth-averaged freesurface model is based on the so-called shallow sea (Reynolds) equations. In our case it is forced by the wind data from the Vilsandi meteorological station and by open boundary sea level variations according to the tide gauges of Ristna or Sõrve. The model provides both the sea level variations and depth-averaged currents in the grid points (see e.g. $[10,11]$ for details and other applications).

A high-resolution Väike Strait model grid (2822 points) with a spatial resolution of $200 \mathrm{~m}$ was nested within that coarser grid. Water fluxes are allowed through the borders of the model. The final simulations of currents and water exchange were carried out within this modelling domain (Fig. 2). For facilitating the interpretation, water fluxes, water exchange and so-called residence times of water are calculated for different realistic and simplified forcing conditions, as well as for some dam-opening options within the six designated sub-areas (or "boxes", Fig. 1, Table 2). The dam is "closed" for the present situation and entirely "open" for the past or one marginal state. One point-size opening with the depth of $0.2 \mathrm{~m}$ represents the originally planned two 1 meter-deep "actual" holes with the width of $20 \mathrm{~m}$ (as they were initially planned for the dam).

\section{Results and discussion}

\subsection{Ecological conditions in the past and present}

In the SE-bay the relatively nutrient-rich Gulf of Riga waters prevail. The Väinameri, including the NW part of the study area (Fig. 2) functions as a kind of buffer zone, where the influence of more saline and nutrient poor water masses of the Baltic Proper is more pronounced. Typical nutrient concentrations in the Väinameri are $0.2-0.3 \mu \mathrm{M}$ P-PO4, 0.3-0.5 $\mu \mathrm{M}$ Ptot, 0.1-0.6 $\mu \mathrm{M}$ N-NO3 and $10-15 \mu \mathrm{M}$ Ntot versus $0.3-0.5 \mu \mathrm{M}$ P-PO4, 0.4-0.7 $\mu \mathrm{M}$ Ptot, $0.5-1.3 \mu \mathrm{M}$ NNO3 and 15-25 $\mu \mathrm{M}$ Ntot in the northern part of the Gulf of Riga in autumn in roughly similar conditions [2,4]. In summer 1993 the average concentration of total phosphorus was $0.74 \mu \mathrm{M}$ in the NW-bay versus $1 \mu \mathrm{M}$ in the SE-bay. Respective values for the total nitrogen were $33 \mu \mathrm{M}$ vs. $44 \mu \mathrm{M}$ [3]. In 2008, the values for Ptot were 1.1 times and for Ntot 1.8 times higher in the SE part compared with the NW-bay [7]. The difference could easily be up to 2-3 folds on different sides of the dam. The dam therefore replaces the hydrochemical front, which in natural conditions pulsates somewhere between the Suur and Hari Strait [11], depending on the prevailing winds and currents (Fig. 3). 


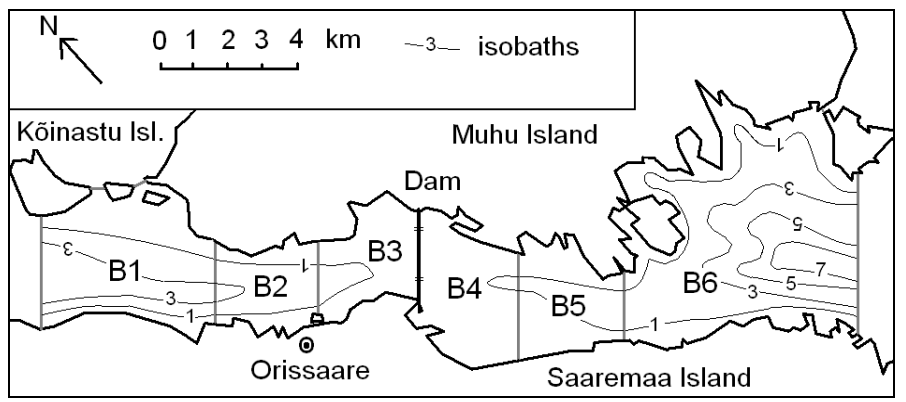

Figure 2: Bathymetry of the Väike Strait and its division into sub-areas ("boxes" B1, etc., see also Table 1 for their measures).

According to our flow and matter exchange measurements in 1993-1996, as well as water exchange modelling [10], the annual sum of southward and northward fluxes through the Suur Strait is about 120-140 and 150-170 km respectively. The positive freshwater balance of about $30 \mathrm{~km}^{3}$ appears due to riverine inflow. The flows in the straits vary depending mainly on wind direction (Fig. 4) and compensating each other in order to maintain (together with sea level variations) water balance. The hypothetical role of the Väike Strait can be seen in Fig. 4. However, the water fluxes in this shallow strait would have been about 10-20 times smaller than that of the Suur Strait. Thus, the Väike Strait would not influence the ecological conditions of the Gulf of Riga or the Väinameri (Fig. 3). But the existence or absence of the dam obviously influences the Väike Strait itself.

Some evidence of local pollution was found near Orissaare in 1970s-1990s [3]. In 1998 a new wastewater treating plant has been built in Orissaare and there should be no remarkable local pollution anymore. According to investigations of phytoplankton, shore and benthic vegetation, the eutrophication is more evident in the SE-bay [6]. Macrophytes and mud appear in the shallow parts of the sea and in the vicinity of the dam. The spawning grounds of fish, especially of whitefish, have been disturbed and fishery catches from this area have decreased [3]. These developments are in general of local character and pelagic zone is not suffering more than the Gulf of Riga as a whole.

The original dam was made of local building materials and infiltration through the dam evidently took place. After the reconstructions in 1990-1996 the dam was made higher and much more solid. As a result, during the next ten years the eutrophication has been allegedly accelerating. The appearance of the shoal in the middle of the SE-bay has also been associated mainly with the new and "thick" dam. Actually, these developments could, firstly, be in relation with the intensifying of the eutrophication processes around the whole marine coastal region of Estonia [2, 6]. Though during the last 5-10 years the overall pollution load has decreased in Estonia, the monitoring data on nutrients still shows large natural variability, which does not allow any straightforward conclusions. Also, reaction of the marine environmental processes takes place with a time-lag and in most cases it is difficult to point out a certain reason. 


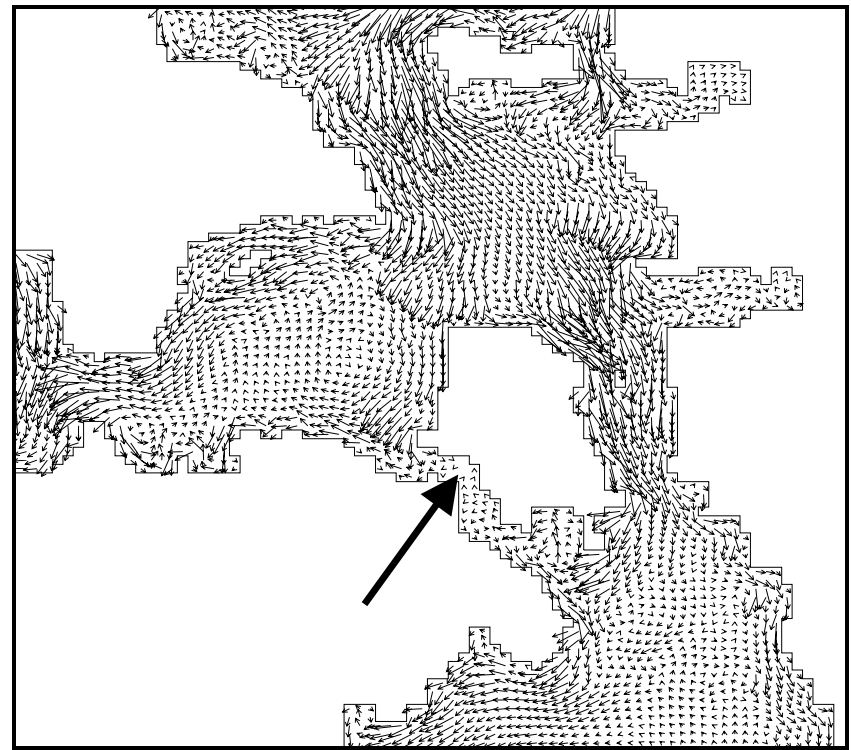

Figure 3: Modelled snapshot of current velocities showing fast currents in the Suur Strait, but lack of fluxes through the Väike Strait (indicated with arrow). $\mathrm{N}$ wind $12 \mathrm{~m} / \mathrm{s}$.

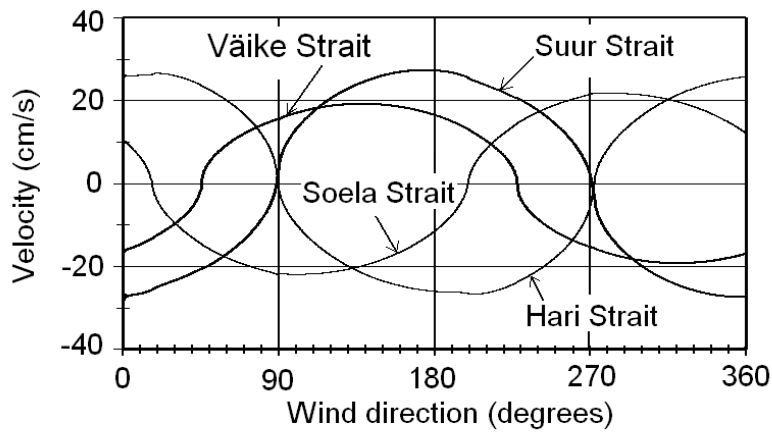

Figure 4: $\quad$ Modelled velocities in the straits of the Väinameri (see Fig. 1) depending on the direction of the stationary wind (with module $7 \mathrm{~m} / \mathrm{s}$, uniform wind over the whole study area). The Väike Strait is entirely open here, as it was before 1896 .

Secondly, the Archipelago sea area has experienced post-glacial isostatic land uplift with a rate of about $2-2.5 \mathrm{~mm} / \mathrm{yr}$ [12]. Due to this natural cause alone the Väike Strait became shallower by about $20-25 \mathrm{~cm}$ over the last 110 years. As the average depth of the strait is below $1 \mathrm{~m}$, this could have had a substantial effect on the area. An additional effect of local sedimentation and siltation could be 
even more pronounced [7]. However, the last estimations put the climate changeinduced global sea level rise rate at about $1.7 \mathrm{~mm} / \mathrm{yr}[8,13]$, which now already roughly compensates for the land uplift in the Väike Strait area. Most likely the sea level rise accelerates and will exceed the uplift during the 21 st century [14].

\subsection{Possible changes in water exchange in re-opening of the strait}

The flow simulations showed that the currents occur as a combination of winddriven circulation and sea level variation-induced back and forth movements of water. The latter role is between 12 and 44\% (Table 1). Despite the absence of tides, the variable wind creates the average sea level fluctuations of about 10-20 $\mathrm{cm}$ per day, which captures about $20 \%$ of the average water volume of the shallow B3 and B4 (Fig. 2).

The maximum current velocity (as simulated with $20 \mathrm{~m} / \mathrm{s}$ sustained wind speed) may reach $80 \mathrm{~cm} / \mathrm{s}$ only in the B4, being $25-40 \mathrm{~cm} / \mathrm{s}$ in the rest of the areas. Still, the depth-averaged flows (Fig. 5) are larger in deeper boxes, especially in B6. Surprisingly, the maximum velocities increased in "without dam" (WD) scenario two-fold in B3, B4 and B5, but just about 20\% in B1, B2 and B6. Larger increase in circulation is prohibited by the shallowness of B3 and B4, which form a "bottle neck". Even in the full-open Väike Strait, the major part of the circulation would still take place in the mouth sections (B1, B6) and the transit turnover of water would not increase that much, as one can expect.

Table 1: Characteristics of the sub-areas ("boxes", see also Fig. 2) and the results of water exchange calculations as control simulation (CS), with two openings in the dam (2O) and without the dam (WD).

\begin{tabular}{|c|c|c|c|c|c|c|}
\hline \multirow[t]{2}{*}{ Characteristic } & \multicolumn{6}{|c|}{ Boxes: in total $0.23 \mathrm{~km}^{3}$, area $113 \mathrm{~km}^{2}$} \\
\hline & B1 & $\mathrm{B} 2$ & B3 & B4 & B5 & B6 \\
\hline Box water volume $\left(\mathrm{km}^{3}\right)$ & 0.048 & 0.010 & 0.005 & 0.004 & 0.006 & 0.15 \\
\hline Box surface area $\left(\mathrm{km}^{2}\right)$ & 23.5 & 7.5 & 8.3 & 11.4 & 9.3 & 52.9 \\
\hline Average depth (m) & 2.1 & 1.3 & 0.6 & 0.4 & 0.7 & 2.9 \\
\hline Water exchange $\mathrm{CS}\left(\mathrm{m}^{3} / \mathrm{s}\right)$ & 365 & 133 & 65 & 60 & 104 & 951 \\
\hline Role of sea level variations (\%) & 14 & 13 & 29 & 44 & 20 & 12 \\
\hline Water exchange $2 \mathrm{O}\left(\mathrm{m}^{3} / \mathrm{s}\right)$ & 365 & 132 & 69 & 67 & 106 & 950 \\
\hline Water exchange WD $\left(\mathrm{m}^{3} / \mathrm{s}\right)$ & 360 & 142 & 118 & 120 & 131 & 932 \\
\hline Residence time CS (d) & 1.53 & 0.84 & 0.88 & 0.85 & 0.68 & 1.85 \\
\hline Residence time $2 \mathrm{O}$ (d) & 1.53 & 0.86 & 0.82 & 0.75 & 0.67 & 1.85 \\
\hline Residence time WD (d) & 1.56 & 0.79 & 0.48 & 0.42 & 0.54 & 1.89 \\
\hline Relative res.time CS $\left(\mathrm{d} / \mathrm{km}^{3}\right)$ & 32 & 87 & 179 & 195 & 112 & 12 \\
\hline Relative res.time $2 \mathrm{O}\left(\mathrm{d} / \mathrm{km}^{3}\right)$ & 32 & 88 & 167 & 172 & 109 & 12 \\
\hline Relative res.time WD $\left(\mathrm{d} / \mathrm{km}^{3}\right)$ & 32 & 82 & 98 & 97 & 88 & 12 \\
\hline Change $2 \mathrm{O}(\%)$ & -0.1 & -2.0 & 6.5 & 11.5 & 2.4 & -0.1 \\
\hline Change WD (\%) & -1.7 & 5.6 & 45.2 & 50.2 & 20.8 & -2.1 \\
\hline
\end{tabular}


As a control run (CR, Table 1), we calculated the average water exchange (representing all the realistic winds in an annual cycle) of the sub-areas. Individual flows can both enter and leave through the box interfaces. The water exchange $\left(\mathrm{m}^{3} / \mathrm{s}\right)$ was defined as a sum of flows entering a box through one (i.e. the "left") border and leaving through another ("right") border. The residence time of water was calculated as an average period when all the water in a box would be replaced by the water from the neighbouring areas. It appeared that this period is between 0.7 and 1.9 days only (Table 1). I.e., quite a busy water turnover proceeds even in the fully closed strait and by no means the area can be regarded as a stagnant one. The main explanation is the shallowness. The relative residence time (per $1 \mathrm{~km}^{3}$ ) is up to 200 days, however. The same calculations were performed also with two openings (2O) as well as for the full open (WD) strait (Table 1) and between the scenarios the relative changes in the water exchange were found. That change included an increase by $6-12 \%$ only in B3 and B4, and virtually no changes in the other sub-areas of the Väike Strait.

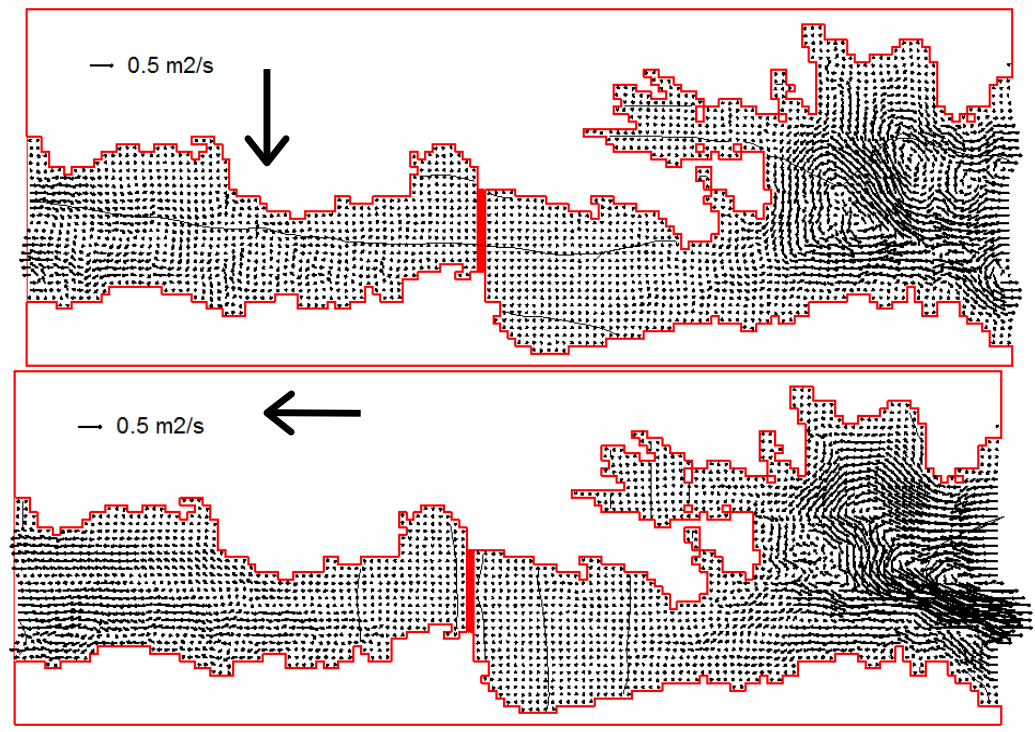

Figure 5: $\quad$ Modelled depth averaged water fluxes and local sea level isolines in case of $7 \mathrm{~m} / \mathrm{s}$ NE (upper figure) and SE winds (lower figure).

\subsection{Possible ecological effect of openings}

Obviously, the initially planned $2 \times 20 \mathrm{~m}$ openings are too small to have any considerable effect for the matter exchange between the Gulf of Riga and the Väinameri, or even for the Väike Strait as a whole. Even if the velocities in the holes may reach 150-200 cm/s (Fig. 6b), the fluxes cannot level out the sea level differences (Fig. 6a), which appear due to wind-generated pile-up and which tend quickly to turn around due to natural wind variability (Fig. 7). 


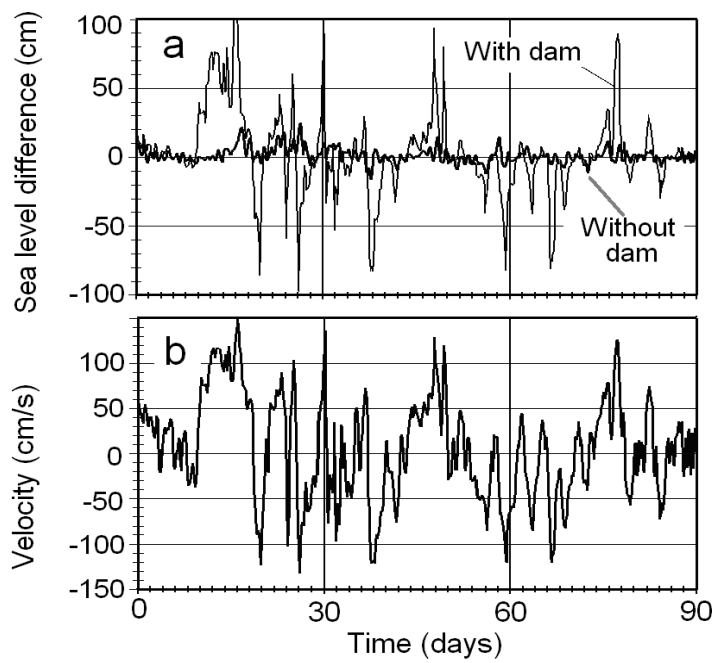

Figure 6: An excerpt of modelled sea level differences (with realistic forcing) between the NW and SE sides of the dam ("with dam") and hypothetically, if there were no dam (a). The velocities through the openings as a result of sea level differences ("with dam", b).
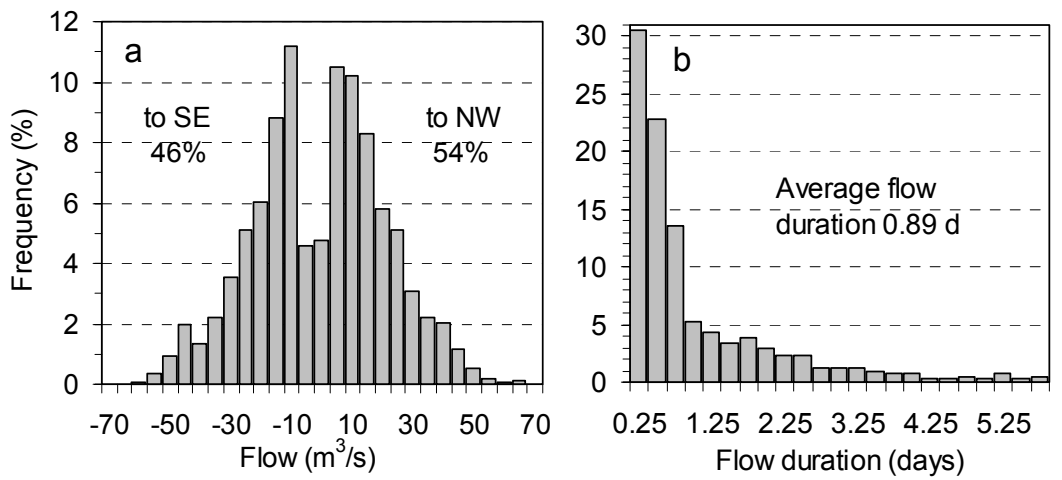

Figure 7: Histograms of the modelled individual flow volumes through the openings throughout one annual cycle (a). The flow direction to NW is slightly preferred due to corresponding statistics of wind directions and sea level differences. Histograms of flow durations (periods between flow reverses; $b$ ).

Bearing in mind the mainly rapidly changing back and forth flows (Fig. 7), the increase in water exchange by $6-12 \%$ (Table 1) means that as a result of openings the water masses in B3 and B4 will be mixed with each other according to that proportion. I.e., if the ingredient concentration were respectively 1 and 2 , they will become more like 1.1 and 1.9. The change in other boxes will be 
negligible. Thus, the water quality will slightly improve in the SE part of the strait and slightly deteriorate in the NW side of the dam, but such changes will be visible only within a few kilometres from the dam.

Another important question is whether the increased flow velocities will increase resuspension by acting on the seabed? The present-time velocities (up to $30 \mathrm{~cm} / \mathrm{s}, 80 \mathrm{~cm} / \mathrm{s}$ in B4) can occasionally re-suspend the bottom sediments as the critical bottom shear of $0.5 \mathrm{dyn} / \mathrm{cm}^{2}$ for fine sand is exceeded in velocities over $20 \mathrm{~cm} / \mathrm{s}[10,15]$. Still, the increase in flow speed counts for about $10 \%$ in $1-2$ $\mathrm{km}$ from the holes and much less in more remote areas. Much higher resuspension occurs as a result of orbital velocities of waves (Fig. 8), although the wave growth is limited by small depth and restricted fetches in the Väike Strait. Therefore the intensity of resuspension depends more on natural changes in wind speed and storminess, and less on the holes in the dam. We admit, however, that due to occasional large velocities in the openings, there may be some noticeable effect in the vicinity (say, within $50-100 \mathrm{~m}$ ) of the openings, but the influence diminishes roughly proportionally with the second power of the distance.

\subsection{Future developments due to anticipated changes in global, regional and local scales}

The trophic status and ecological conditions will still mainly depend on the overall state of the Gulf of Riga, in one side, and that of the Väinameri, in the other side. According to present wind and sea level statistics (Figs. 9, 7), the NW flows would be prevail, yielding about $0.1 \mathrm{~km}^{3} / \mathrm{yr}$ resulted NW flow [5]. The corresponding matter fluxes are not remarkable, as compared e.g. to the resulted annual northward flow of about $30 \mathrm{~km}^{3}$ through the Suur Strait. However, the resulted flow direction depends on a year.
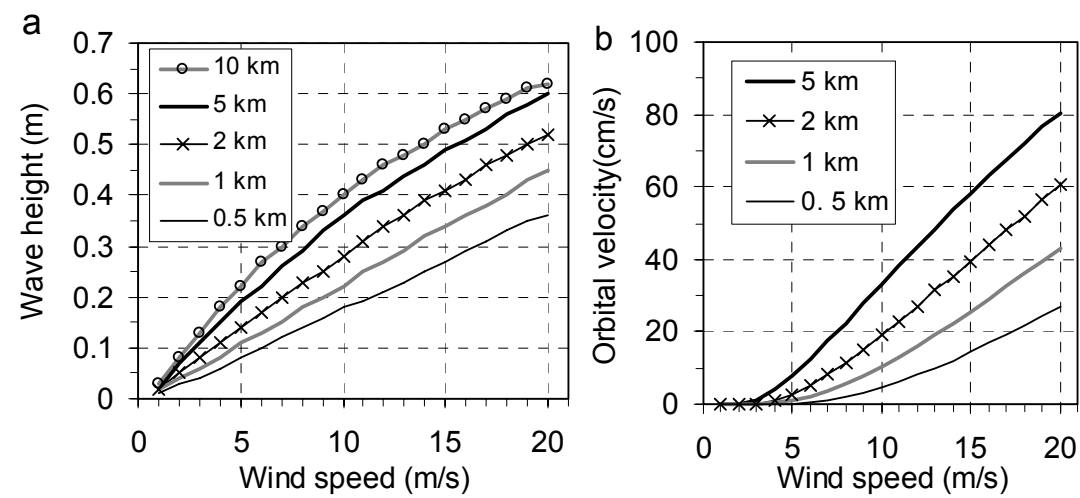

Figure 8: $\quad$ Modelled dependence between significant wave height and wind speeds in different fetches $(\mathrm{km})$ considering the average depth $(2 \mathrm{~m})$ of the Väike Strait (a); dependence between wind speed and corresponding maximum near-bottom $(<10 \mathrm{~cm})$ orbital velocities (b). The calculations with the SMB-model; see e.g. $[15,16]$. 

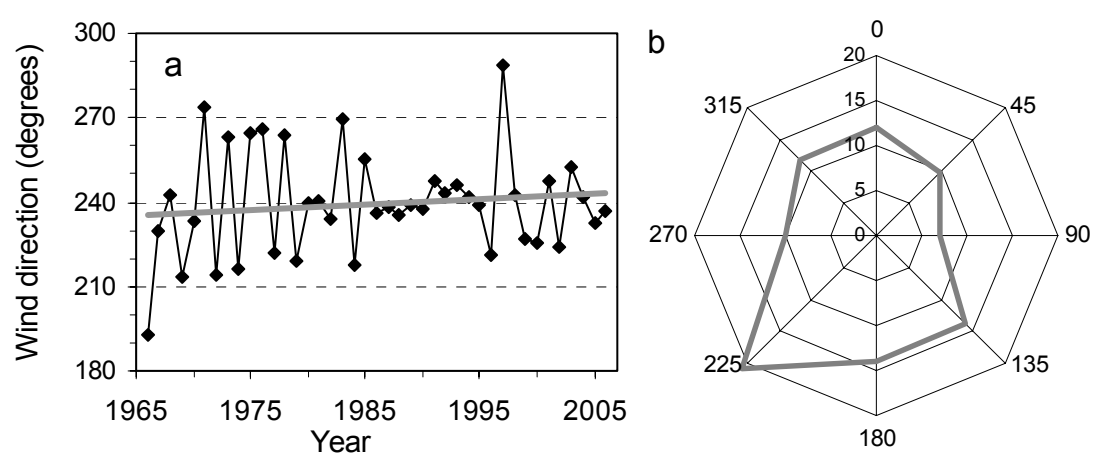

Figure 9: The long term average wind rose (b) and decadal variations in annual average resulted wind directions at the Vilsandi station (a); the directions were calculated from 3-hourly wind speed components.

According to the long-term changes in regional wind regime, the annual average wind directions turn from SW to WSW (Fig. 9), yielding less NW and more SE flow. As it was also pointed out before, due to anticipated acceleration of global sea level rise [11, 13, 14], the Väike Strait will not turn any shallower any more, but likely the average depth of that very shallow area will increase. This will ease some (seeming) problems of silting up and congestion of the strait, and more that than the openings would do.

\section{Conclusions}

Water renewal as a result of wind-driven currents and water level fluctuations is surprisingly busy in the Väike strait area, but mainly due to shallowness. The planned $(2 \times 20 \mathrm{~m})$ openings have a minor positive effect on water renewal or nutrient exchange rates. The water exchange, depending on the scenario, will increase only by about $6-12 \%$, and yet in the zones nearby the dam. Even if the size of the strait looks just about a half of that of the Suur Strait, it is much shallower, the flows are hampered by large friction and the water exchange with the openings in the dam would be about 300 times (and in the hypothetical case of fully open strait, about 20 times) smaller than in the Suur Strait. Most of the past changes in the Väike Strait have probably occurred either due to natural or of larger scale causes, such as isostatic land uplift, natural sedimentation and overall eutrophication of the sea. As it is common with natural system, you can't turn back the time - e.g., merely by constructing openings, or even by entirely re-opening the strait. In the nearest future, the anticipated increase in storminess, accelerating sea level rise and ability with coping regional pollution problems will become decisive factors also for the Väike Strait.

\section{Acknowledgements}

The study was supported by the ESF grant 7609 and the SF theme $0180104 \mathrm{~s} 08$. 


\section{References}

[1] HELCOM, The Baltic marine environment 1999-2002. Balt. Sea Environ. Proc., 87, Helsinki Commission: Helsinki, 2003.

[2] Ojaveer, E. (ed.), Ecosystem of the Gulf of Riga between 1920 and 1990. Estonian Academy Publishers: Tallinn, 277 pp., 1995.

[3] Ecological studies in the Aquatic Environment of Väike Väin Strait in West Estonia. Estonian-Finnish cowork during summer 1993. Report. Helsinki, Kuressaare, 1994.

[4] Porgassaar, V., Content and distribution of phosphorus and nitrogen in the coastal waters of West Estonia. Proc. Estonian Acad. Sci. Ecol., 3, pp. 166180, 1993.

[5] Suursaar, Ü., Otsmann, M. \& Kullas, T., Exchange processes in the Väike Strait (the Baltic Sea): present, past, future. Proc. Estonian Acad. Sci. Biol. Ecol., 49, pp. 235-252, 2000.

[6] Martin, G. (ed.), Monitoring of the coastal sea in 2007. Report. Estonian Marine Institute, Ministry of Environment: Tallinn, 113 pp., 2008. http://eelis.ic.envir.ee:88/seireveeb/aruanded/8070_ylevaateseire.doc.

[7] Lutt, J., Bottom sediments of the Väinameri. Valgus: Tallinn, 239 pp., 1985. [in Russian].

[8] Suursaar, Ü. \& Sooäär J., Decadal variations in mean and extreme sea level values along the Estonian coast of the Baltic Sea. Tellus A, 59, pp. 249 260, 2007.

[9] Otsmann, M., Suursaar, Ü. \& Kullas, T., The oscillatory nature of the flows in the system of straits and small semienclosed basins of the Baltic Sea. Continental Shelf Research, 21, pp. 1577-1603, 2001.

[10] Suursaar, Ü., Kullas, T. \& Otsmann, M., The influence of currents and waves on ecological conditions of the Väinameri. Proc. Estonian Acad. Sci. Biol. Ecol., 50, pp. 231-247, 2001.

[11] Suursaar, Ü. \& Kullas, T., Influence of wind climate changes on the mean sea level and current regime in the coastal waters of west Estonia, Baltic Sea. Oceanologia, 48, pp. 361-383, 2006.

[12] Vallner, L., Sildvee, H. \& Torim, A., Recent crustal movements in Estonia. J. Geodyn., 9, pp. 215-223, 1988.

[13] Church, J.A. \& White, N.J., A 20th century acceleration in global sea-level rise. Geophys. Res. Lett., 33, L01602, 2006.

[14] Jylhä, K., Tuomenvirta, H. \& Rusteenoja, K., Climate change projections for Finland during the 21st century. Boreal Environment Research, 9, pp. 127-152, 2004.

[15] Huttula, T., Suspended sediment transport in Lake Säkylän Pyhäjärvi, Aqua Fennica, 24, pp. 171-185, 1994.

[16] Suursaar, Ü. \& Kullas, T., Decadal variations in wave heights off Cape Kelba, Saaremaa Island, and their relationships with changes in wind climate. Oceanologia, 51, pp. 39-61, 2009. 